\title{
Valor da Avaliação Propedêutica Objetiva e Subjetiva no Diagnóstico da Incontinência Urinária Feminina. Correlação com a Força Muscular do Assoalho Pélvico
}

Autora: Eliane Cristina Hilberath Moreira

Orientador: Prof. Dr. João Luiz Amaro

Dissertação apresentada ao curso de Pós-Graduação em Ginecologia e Obstetrícia da Faculdade de Medicina da Universidade Estadual Paulista - UNESP, Campus de Botucatu, para obtenção do título de Mestre em Ginecologia no dia 21 de setembro de 1999.

A incontinência urinária feminina continua sendo um tema atual e controverso. O propósito deste estudo foi de comparar o valor da avaliação propedêutica objetiva e subjetiva no diagnóstico da incontinência urinária, assim como avaliar a influência da força muscular do assoalho pélvico. Foram estudadas 101 mulheres distribuídas em dois grupos, sendo o grupo $1(n=51)$, com perda urinária e grupo $2(n=50)$, sem perda urinária. Foram estudados os seguintes parâmetros: 1- avaliação clínica; 2- teste do absorvente; 3- avaliação visual, funcional e objetiva dos músculos do assoalho pélvico. Os resultados obtidos nos permitiram concluir que: a média do índice de massa corporal no G1 foi de $28 \%$ e no G2 foi de $24 \%$ demonstrando que a obesidade é um fator predisponente na incontinência urinária $(\mathrm{p}<0,05)$. $\mathrm{O}$ número de micções diário em média foi no $\mathrm{G} 1$ de
$6,47$, e de 5,96 no G2 ( $\mathrm{p}<0,05)$. Notamos que $25 \%$ das mulheres $\mathrm{d}$ G1 foram capazes de interromper o jato urinário contra $80 \%$ do $\mathrm{G} 2(\mathrm{p}<0,05)$. A avaliação objetiva e funcional da força muscular nas mulheres incontinentes revelou um déficit significativo na força muscular e na percepção do assoalho pélvico quando comparado ao grupo de mulheres continentes. Observouse comparando os resultados da avaliação subjetiva e objetiva, uma concordância entre estas duas modalidades de avaliação em $57 \%$ dos casos e em $41 \%$ os dados são superestimados pela avaliação subjetiva. A força muscular do assoalho pélvico foi deficitária nas mulheres incontinentes.

Palavras-chave: Incontinência urinária. Obesidade. do Papiloma Virus Humano em Lesões do Colo Uterino de Mulheres Infectadas pelo Virus da Imunodeficiência Humana

\author{
Autora: Néli Sueli Teixeira de Souza
}

Orientador: Victor Hugo de Melo

Tese apresentado ao Curso de Pós-Graduação em Ginecologia e Obstetrícia da Universidade Federal de Minas Gerais em 19 de maio de 2000.

Foram estudadas 52 pacientes soropositivas para o HIV com lesões cervicais clinicamente suspeitas de HPV nas quais se realizou coleta de material (raspado) da cérvice uterina para a PCR e biópsia dirigida pela colposcopia, para o estudo histopatológico. As amostras de três pacientes se mostraram sem qualidade para a PCR e foram consideradas como "perdas". Dentre as 49 pacientes restantes a prevalência de HPV foi de $53 \%$ através do estudo histopatológico e de $85,7 \%$ pela PCR. A idade do grupo estudado variou de 17 a 54 anos, com mediana de 32 anos. A forma de contágio para HIV foi a heterossexual em 95,7\% dos casos e $75,5 \%$ das pacientes tiveram de 1 a 3 parceiros sexuais em toda a vida. A queixa mais freqüente foi corrimento vaginal $(39,6 \%)$ e $34,7 \%$ procuraram o serviço apenas para consulta de rotina. Dentre as 42 pacientes com HPV, detectado pela PCR, somente 26 foram confirmadas pela histopatologia ( $\mathrm{S}=61,9 \%)$. Esta, por sua vez, não demonstrou nenhum resultado falso-positivo $(\mathrm{E}=100 \%)$. Comparando-se os dois resultados encontrou-se, para a histopatologia: Valor Preditivo Positivo $=100 \%$ e Valor Preditivo Negativo $=30,4 \%$. Das 26 pacientes com histopatologia positiva para HPV, 15 $(57,6 \%)$ apresentaram neoplasias intra-epiteliais cervicais (NIC); $R R=13,27$. Conclusão: a histopatologia mostrou $100 \%$ de acerto para o diagnóstico de HPV, o que significa dizer que, quando a biópsia for positiva, o HPV certamente estará presente, confirmando a suspeita clínica. No entanto, a baixa sensibilidade retira da histopatologia o valor como exame de rastreamento nesse grupo de mulheres.

Palavras-chave: AIDS. Reação de polimerase em cadeia. HPV. Colpocitologia. 